\title{
The Present Relationship between Japanese Workers' Health Status and Lifestyle
}

\author{
Ichiro Sakurada ${ }^{1}$, Yasushi OKubo ${ }^{1}$, Yasushi Suwazono ${ }^{1}$, Etsuko Kobayashi ${ }^{1}$, \\ Koji NogAwA ${ }^{1}$, Teruhiko KIDO ${ }^{2}$ and Natsuo KINOUCHI ${ }^{3}$ \\ ' Department of Hygiene, Chiba University School of Medicine, ${ }^{2}$ Department of Community Health \\ Nursing, Kanazawa University School of Health Science and ${ }^{3}$ Kinugawa Rubber Industry Co. Ltd.
}

\begin{abstract}
The Present Relationship between Japanese Workers' Health Status and Lifestyle: Ichiro Saxurada, et al. Department of Hygiene, Chiba University School of Medicine-To clarify the factors of lifestyle which are really relevant to present Japanese industrial workers' health, the relationship between physical or mental health status and lifestyle among workers of three different companies in Japan (2265 male) was investigated. The indices of physical health status investigated here were as follows: SBP, DBP, GOT, GPT, $\mu$ GTP, T-CHO, TG, RBC, Hb. The index of mental health status was SDS. The explanatory variables were age, nine lifestyle factors, and obesity index. Age and obesity index were statistically significant to physical health status in the three companies. The relationship between health status and the other lifestyle factors differed among the three companies. The lifestyle factors which were significant to the mental health status differed among the three companies. These results suggest that the management of obesity may be the most important issue for present day Japanese industrial workers. But the focus of effective mental health education differed among the three companies.
\end{abstract}

(J Occup Health 1999; 41: 69-75)

Key words: Physical health status, Mental health status, Lifestyle, Worker, Obesity

Breslow pointed out that seven kinds of lifestyle affect health status ${ }^{1-4\rangle}$. Morimoto conducted studies concerning the relationship between health status and lifestyle in a working population ${ }^{5-7)}$. His results did not contradict the reports by Breslow. And now it has been clarified that lifestyle is relevant not only to health status but also

Received Jul 23, 1998; Accepted Dec 9, 1998

Correspondence to: 1 . Sakurada, Department of Hygiene, Chiba University School of Medicine, 1-8-1 Inohana, Chuoku, Chiba 2608670 , Japan constitutes a cause of some disease ${ }^{\gamma-9)}$.

According to the information based on those studies, advice on daily life has been given to Japanese industrial workers, especially to workers who have any trouble with physical health. In Japan, all employers are under obligation to make workers undergo medical examinations. The Industrial Safety and Health Law has enforced this obligation. Health care based on the results of medical examinations such as health education by an industrial physician or a public health nurse has been an obligation since 1996.

On the other hand, mental health care has just begun among Japanese industrial works. Many problems related to mental health have become evident paralleling changes in the working environment or changes in the style of employment such as the abolishment of lifetime employment.

Under these working conditions, we thought it important to identify the lifestyle factors which are the most relevant to present day Japanese industrial workers' health and to adequately measure workers' health. This prompted to us perform a cross-sectional study on the relationship between physical or mental health status and lifestyle among Japanese workers in three different companies.

\section{Methods}

The target companies of this investigation were a rubber-product manufacturing company (K Company), an electric-device manufacturing company (H Company), and an aluminum-product manufacturing company ( $Y$ Company).

The data for all male workers who underwent a medical examination at each company were analyzed. A total of 1,200 male workers in $\mathrm{K}$ Company, 649 male workers in $\mathrm{H}$ company, and 416 male workers in Y Company were examined (Table 1).

Workers in K Company worked in two shifts, and the 
Table 1. Number of workers

\begin{tabular}{lcrrr}
\hline & Company K & Company H & Company Y & All workers \\
\hline 20 y.o. or younger & 9 & 10 & 1 & 20 \\
$20 \sim 29$ y.o. & 303 & 194 & 222 & 719 \\
$30 \sim 39$ y.o. & 279 & 109 & 177 & 565 \\
$40 \sim 49$ y.o. & 326 & 194 & 14 & 534 \\
$50 \sim 59$ y.o. & 278 & 142 & 1 & 421 \\
60 y.o. or elder & 5 & 0 & 1 & 6 \\
\hline \\
Total
\end{tabular}

Table 2. Mean values of indices of health status of workers

\begin{tabular}{lrrrrr}
\hline & \multicolumn{1}{c}{ K Company } & \multicolumn{1}{c}{ H Company } & \multicolumn{2}{c}{ Y Company } \\
\hline SBP $(\mathrm{mmHg})$ & $127.3 \pm 14.1$ & $126.6 \pm 13.6$ & $121.5 \pm 13.6$ \\
DBP $(\mathrm{mmHg})$ & $78.4 \pm 10.7$ & $77.3 \pm 10.4$ & $76.1 \pm 10.6$ \\
GOT $(\mathrm{IU} / l)$ & $25.3 \pm 13.8$ & $25.0 \pm 10.8$ & $24.2 \pm$ & 8.0 \\
GPT $(\mathrm{IU} / l)$ & $25.3 \pm 13.8$ & $30.2 \pm 21.2$ & $29.0 \pm 21.8$ \\
$\gamma \mathrm{GTP}(\mathrm{IU} / l)$ & $48.4 \pm 68.9$ & $41.4 \pm 44.9$ & $32.9 \pm 29.4$ \\
$\mathrm{~T}-\mathrm{CHO}(\mathrm{mg} / \mathrm{d} l)$ & $191.3 \pm 35.1$ & $183.7 \pm 32.7$ & $175.9 \pm 31.9$ \\
TG $(\mathrm{mg} / \mathrm{d} l)$ & $177.8 \pm 161.5$ & $148.0 \pm 107.1$ & $95.4 \pm 70.6$ \\
$\mathrm{RBC}\left(10^{4} / \mu l\right)$ & $487.6 \pm 38.9$ & $483.0 \pm 37.1$ & $494.1 \pm 29.9$ \\
$\mathrm{Hb}(\mathrm{g} / \mathrm{d} l)$ & $15.1 \pm 1.0$ & $15.0 \pm 1.0$ & $15.4 \pm$ & 0.8 \\
\hline SDS & $40.0 \pm 8.0$ & $40.2 \pm 7.9$ & $38.5 \pm$ & 7.0 \\
\hline
\end{tabular}

Mean \pm standard deviation.

majority of them had graduated from high school. Workers in H Company worked in three shifts with the majority of them also having graduated from high school. Workers in Y Company were on day work and the majority of them were university graduates.

In this study, systolic blood pressure (SBP), diastolic blood pressure (DBP), GOT, GPT, $\gamma$-GTP, total cholesterol ( $\mathrm{T}-\mathrm{CHO}$ ), triglyceride (TG), $\mathrm{RBC}$, and hemoglobin $(\mathrm{Hb})$ were used as indices of physical health status and were obtained from the health examination data. The Self-rating Depression Scale score (SDS) ${ }^{10-12)}$ was used as an index of mental health status (Table 2).

Information on sleeping time, working time, number of holidays per month, eating breakfast, eating snacks, consumption of soft drinks, consumption of alcohol, smoking, and habitual physical exercise was obtained by means of a questionnaire at the time of the health examination, and was used as the explanatory variables. The obesity index was included in the explanatory variables of lifestyle as a factor reflecting behavior in daily life.

Nine indices of physical health status, SDS, age, and obesity index were treated as quantitative variables, and the explanatory variables of lifestyle except the obesity index were treated as qualitative variables, as shown in Table 3.

The general linear models (GLM) were used to analyze the relationship between the physical or mental health status and lifestyle of workers in each company and all workers examined. The formula for the GLM procedure was as follows:

Physical or mental health status $=\beta_{0}+\beta_{1} \times($ age $)+\beta_{2}$ $\times($ sleep time $)+\beta_{3} \times($ work time $)+\beta_{4} \times$ (holiday $)$ $+\boldsymbol{\beta}_{5} \times($ breakfast $)+\boldsymbol{\beta}_{6} \times($ snack $)+\boldsymbol{\beta}_{7} \times($ soft drink $)$

$+\beta_{8} \times($ alcohol $)+\beta_{9} \times($ smoking $)+\beta_{10} \times$ (exercise $)$ $+\beta_{11} \times$ (obesity index)

where $\beta_{0}-\beta_{11}$ are coefficients. GLM were performed with SAS/STAT software.

\section{Results}

\section{Relationship between Physical Health Status and Lifestyle}

The results of analysis of all workers are shown in Table 4-1. The results of analysis for each company are shown in Tables 4-2, 4-3 and 4-4.

According to the results of the analysis of all workers, the obesity index was significant in all indices of physical 
Table 3. Lifestyle of workers (\%)

\begin{tabular}{|c|c|c|c|}
\hline & K Company & H Company & Y Company \\
\hline \multicolumn{4}{|l|}{ Sleep Time / day } \\
\hline 5 hours or less & 4.4 & 4.4 & 9.2 \\
\hline 6 hours & 36.9 & 35.3 & 55.9 \\
\hline 7 hours & 43.8 & 43.3 & 31.7 \\
\hline 8 hours & 14.4 & 16.4 & 3.2 \\
\hline 9 hours or more & 0.5 & 0.7 & 0 \\
\hline \multicolumn{4}{|l|}{ Work Time / day } \\
\hline 8 hours or less & 3.3 & 9.8 & 1.2 \\
\hline 9 hours & 48.0 & 66.1 & 17.5 \\
\hline 10 hours & 14.5 & 4.0 & 23.6 \\
\hline 11 hours & 16.2 & 8.6 & 24.2 \\
\hline 12 hours or more & 18.2 & 11.5 & 33.5 \\
\hline \multicolumn{4}{|l|}{ Holidays / month } \\
\hline 5 days or more & 94.3 & 84.3 & 96.3 \\
\hline 4 days or less & 5.7 & 12.7 & 3.7 \\
\hline \multicolumn{4}{|l|}{ Eating Breakfast* } \\
\hline 5 days or more & 70.6 & 73.3 & 57.0 \\
\hline 4 days or less & 29.4 & 26.7 & 43.0 \\
\hline \multicolumn{4}{|l|}{ Eating Snacks* } \\
\hline 5 days or more & 7.9 & 7.7 & 4.4 \\
\hline 4 days or less & 92.1 & 92.3 & 95.6 \\
\hline \multicolumn{4}{|l|}{ Soft drinks* } \\
\hline 5 days or more & 57.5 & 72.6 & 45.5 \\
\hline 4 days or less & 42.5 & 27.4 & 54.5 \\
\hline \multicolumn{4}{|l|}{ Alcohol* } \\
\hline 5 days or more & 31.7 & 39.3 & 33.4 \\
\hline 4 days or less & 68.3 & 60.7 & 66.6 \\
\hline \multicolumn{4}{|l|}{ Smoking } \\
\hline Yes & 62.4 & 66.4 & 63.4 \\
\hline No & 37.6 & 33.6 & 36.6 \\
\hline \multicolumn{4}{|l|}{ Physical Exercise } \\
\hline Yes** & 55.0 & 66.0 & 55.5 \\
\hline No & 45.0 & 34.0 & 44.5 \\
\hline
\end{tabular}

*Frequency of consumption/week. **Habitual Physical Exercise (At least once a week).

Sleeping time ( 5 hours or less $=5,6$ hours $=6,7$ hours $=7,8$ hours $=8,9$ hours or more $=9$ ), Working time ( 8 hours or less $=8$, 9 hours $=9,10$ hours $=10,11$ hours $=11,12$ hours or more $=12$ ), Holiday ( 5 days or more per month $=0,4$ days or less per month $=1$ ), Breakfast ( 4 days or less per week $=0,5$ days or more per week $=1$ ), Snack ( 5 days or more per week $=0,4$ days or less per week $=1$ ), Soft drinks ( 5 days or more per week $=0,4$ days or less per week $=1$ ), Alcohol ( 5 days or more per week $=0,4$ days or less per week=1), Smoking (yes=0, no=1) and Exercise (yes=0, no=1). health status, and age was significant in all indices of physical health status except GPT. Slceping time was significant only in DBP and $\mathrm{Hb}$. Eating breakfast was significant only in SBP. Consumption of alcohol was significant only in SBP, DBP, and $\gamma$ GTP. Smoking was significant only in SBP and $\mathrm{Hb}$. Habitual physical exercise was significant only in RBC.

According to the analysis for each company, the obesity index was significant in all indices of physical health status in all companies. Age was significant in all indices of physical health status except GOT in K Company, significant to DBP,GOT, $\mu$ GTP,T-CHO,RBC, and $\mathrm{Hb}$ in H Company, and significant to SBP,DBP, $\gamma$ GTP,T-CHO, and TG in Y Company. But no lifestyle parameter except the obesity index, which was significant in all indices of physical health status in all three companies, was found.

\section{Relationship between Mental Health Status and Lifestyle}

The results of analysis of all workers and each company are shown in Table 5.

According to the analysis of all workers, age, slecping time, smoking, and habitual physical exercise were significant in SDS which is an index of mental health status. Advancing age and lifestyle parameters such as sleeping longer, smoking and habitual physical exercise had a close relationship to mental health.

But no lifestyle factor significantly related to the index of mental health status in all three companies was found.

\section{Discussion}

Breslow pointed out that seven lifestyle factors (sleeping pattern, eating breakfast, eating snacks, obesity, physical excrcise, smoking and consumption of alcohol) affected health status ${ }^{1-4)}$. Morimoto conducted a double check study concerning the relationship between health status and eight lifestyle factors (cigarette smoking, consumption of alcohol, physical exercise, mental stress, sleeping pattern, nutritional balance, eating breakfast and working pattern) in a working population, and arrived at the same conclusion ${ }^{5)}$.

In recent studies it has been reported that a healthy lifestyle is associated not only with health status and disorders but also with causes of disease such as changes in the immune system ${ }^{8-9)}$.

The fact that the structure of disease or lifestyle varies according to occupation has been confirmed ${ }^{13-17)}$. In working populations, significant relationships between physical health status and lifestyle factors such as dietary habits, consumption of alcohol and smoking have been reported $^{5,18,19)}$.

Takeda reported that the type of occupation might change the lifestyle, as a result of which, physical health status might vary owing to differences in occupation or the type of work ${ }^{20)}$. For example, workers in 
Table 4-1. Coefficients of general linear models in several physical health status parameters of all workers examined

\begin{tabular}{|c|c|c|c|c|c|c|c|c|c|c|c|c|}
\hline \multirow[b]{2}{*}{ Indicators } & \multirow[b]{2}{*}{ Intercept } & \multirow[b]{2}{*}{ Age } & \multicolumn{10}{|c|}{ Coefficients } \\
\hline & & & $\begin{array}{c}\text { Sleep } \\
\text { time }\end{array}$ & $\begin{array}{l}\text { Work } \\
\text { time }\end{array}$ & Holiday & $\begin{array}{c}\text { Break- } \\
\text { fast }\end{array}$ & Snack & $\begin{array}{c}\text { Soft } \\
\text { drinks }\end{array}$ & Alcohol & Smoking & Exercise & $\begin{array}{l}\text { Obesity } \\
\text { Index }\end{array}$ \\
\hline SBP & 116 & $0.183^{* *}$ & 0.177 & -0.245 & -1.30 & $1.59^{*}$ & 0.605 & 1.22 & $-1.42^{*}$ & $-1.31^{*}$ & 0.857 & $0.264 * *$ \\
\hline DBP & 62.3 & $0.261^{* *}$ & $0.775 * *$ & 0.0465 & -1.35 & 0.313 & -0.0690 & 0.909 & $-1.15^{*}$ & -0.163 & 0.723 & $0.192 *$ \\
\hline GOT & 19.5 & $0.0892 * *$ & 0.0702 & 0.145 & -0.737 & 0.309 & -0.00603 & -0.417 & -1.16 & -0.189 & 0.731 & $0.166^{* *}$ \\
\hline GPT & 33.3 & -0.0907 & -0.837 & 0.0796 & -1.28 & 0.811 & -0.311 & -0.336 & 1.35 & -0.282 & 1.39 & $0.649 * *$ \\
\hline$\gamma \mathrm{GTP}$ & 18.6 & $0.573^{* *}$ & 0.860 & -0.0672 & -7.14 & -0.549 & -5.84 & 1.58 & $-11.2 * *$ & -0.683 & 4.59 & $0.472 * *$ \\
\hline Т-CHO & 147 & $0.649 * *$ & 0.485 & 0.162 & -2.18 & 0.125 & 2.81 & -0.650 & 0.735 & 0.786 & 1.75 & $0.742 * *$ \\
\hline $\mathrm{TG}$ & 93.5 & $0.998 * *$ & -2.41 & -0.357 & -17.7 & 2.44 & -17.2 & 0.652 & -0.537 & -13.1 & 11.0 & $2.69^{* *}$ \\
\hline RBC & 524 & $-1.33^{* *}$ & 1.23 & 0.0990 & -3.56 & 1.32 & -5.08 & 1.72 & 3.24 & -1.19 & $3.42^{*}$ & $0.694^{* *}$ \\
\hline $\mathrm{Hb}$ & 15.9 & $-0.0232^{* *}$ & $0.0604^{*}$ & -0.00718 & 0.0480 & -0.0335 & -0.102 & 0.0229 & -0.0599 & $-0.197^{* *}$ & 0.0629 & $0.0187^{* *}$ \\
\hline
\end{tabular}

**Significant $(\mathrm{p}<0.01), *$ Significant $(\mathrm{p}<0.05)$.

Table 4-2. Coefficients of general linear models in several physical health status parameters of workers in $\mathrm{K}$ company

\begin{tabular}{|c|c|c|c|c|c|c|c|c|c|c|c|c|}
\hline \multirow[b]{2}{*}{ Indicators } & \multirow[b]{2}{*}{ Intercept } & \multirow[b]{2}{*}{ Age } & \multicolumn{10}{|c|}{ Coefficients } \\
\hline & & & $\begin{array}{c}\text { Sleep } \\
\text { time }\end{array}$ & $\begin{array}{l}\text { Work } \\
\text { time }\end{array}$ & Holiday & $\begin{array}{c}\text { Break- } \\
\text { fast }\end{array}$ & Snack & $\begin{array}{c}\text { Soft } \\
\text { drinks }\end{array}$ & Alcohol & Smoking & Exercise & $\begin{array}{l}\text { Obesity } \\
\text { Index }\end{array}$ \\
\hline SBP & 124 & $0.241 * *$ & -0.463 & -0.465 & -3.44 & 1.19 & 0.23 & 0.512 & -1.10 & -1.25 & 0.235 & $0.244^{* *}$ \\
\hline DBP & 62.9 & $0.282 * *$ & 0.451 & -0.0208 & $-2.89^{*}$ & -0.354 & 0.852 & 0.804 & -0.365 & -0.541 & 0.152 & $0.172 * *$ \\
\hline GOT & 19 & 0.0732 & 0.291 & 0.146 & -0.399 & -1.06 & -0.949 & -0.0988 & -0.679 & -0.965 & 1.13 & $0.0856^{*}$ \\
\hline GPT & 40.3 & $-0.193^{* *}$ & -0.791 & -0.103 & 0.0669 & -2.64 & -2.50 & -0.479 & 2.38 & -1.22 & 0.554 & $0.512^{* *}$ \\
\hline$\gamma \mathrm{GTP}$ & 8.18 & $0.599 *$ & 3.49 & 0.488 & -8.16 & -4.27 & -15.7 & 2.72 & -8.06 & -5.2 & 5.3 & 0.359 \\
\hline T-CHO & 171 & $0.329^{*}$ & -0.996 & 0.545 & 3.55 & 2.97 & -0.286 & 1.45 & -1.58 & 0.355 & 1.75 & $0.681 * *$ \\
\hline TG & 207 & $1.32 *$ & -8.42 & -1.90 & -34.8 & 14.4 & -41.1 & 5.67 & -2.74 & -6.76 & 9.89 & $3.03 * *$ \\
\hline RBC & 554 & $-1.63 * *$ & -0.571 & 0.154 & -6.93 & 0.787 & -2.39 & $6.28 *$ & 0.528 & $-5.45^{*}$ & 4.12 & $0.745^{* *}$ \\
\hline $\mathbf{I}[\mathbf{b}$ & 16.3 & $-0.0279^{* *}$ & 0.033 & -0.0187 & -0.0615 & 0.0089 & -0.115 & $0.162^{*}$ & 0.031 & $-0.161^{*}$ & 0.0835 & $0.0177^{* *}$ \\
\hline
\end{tabular}

**Significant $(p<0.01), *$ Significant $(p<0.05)$.

Table 4-3. Coefficients of general linear models in several physical health status parameters of workers in $\mathbf{H}$ company

\begin{tabular}{|c|c|c|c|c|c|c|c|c|c|c|c|c|}
\hline \multirow[b]{2}{*}{ Indicators } & \multirow[b]{2}{*}{ Intercept } & \multirow[b]{2}{*}{ Age } & \multicolumn{10}{|c|}{ Coefficients } \\
\hline & & & $\begin{array}{c}\text { Slecp } \\
\text { timc }\end{array}$ & $\begin{array}{l}\text { Work } \\
\text { time }\end{array}$ & Holiday & $\begin{array}{c}\text { Break- } \\
\text { fast }\end{array}$ & Snack & $\begin{array}{c}\text { Soft } \\
\text { drinks }\end{array}$ & Alcohol & Smoking & Exercise & $\begin{array}{l}\text { Obesity } \\
\text { Index }\end{array}$ \\
\hline SBP & 114 & 0.0640 & 0.823 & 0.166 & 0.747 & 1.59 & 3.23 & 2.59 & -1.15 & -2.28 & 1.31 & $0.256^{* *}$ \\
\hline DBP & 58.8 & $0.195^{* *}$ & $1.31^{*}$ & 0.0547 & 0.424 & -0.458 & 0.0271 & $2.24 *$ & -1.39 & -0.775 & $2.09 *$ & $0.182 * *$ \\
\hline GOT & 19.5 & $0.104 * *$ & -0.513 & 0.127 & -0.438 & 0.492 & 1.92 & -0.238 & $-1.73^{*}$ & 0.901 & 0.907 & $0.237 * *$ \\
\hline GPT & 29.4 & -0.00238 & -1.75 & 0.219 & -0.906 & 1.61 & 3.17 & -1.43 & 0.0441 & 0.112 & $3.32 *$ & $0.721^{* *}$ \\
\hline$\gamma$ GTP & 39.4 & $0.474 * *$ & -3.23 & -0.488 & -7.09 & 1.82 & 9.68 & -0.0982 & $-15.9 * *$ & 5.98 & 4.22 & $0.611^{* *}$ \\
\hline T-CHO & 139 & $0.880^{* *}$ & 0.0151 & -0.135 & -6.41 & -1.06 & 3.83 & -3.19 & 3.34 & 2.57 & 4.60 & $0.908^{* *}$ \\
\hline TG & 61.8 & 0.488 & 4.71 & -0.000984 & -6.22 & 3.26 & 17.8 & 1.93 & -1.70 & $-19.4^{*}$ & 12.6 & $2.50 * *$ \\
\hline RBC & 507 & $-1.10^{* * *}$ & 2.21 & 0.170 & -3.52 & 1.82 & -7.55 & -2.44 & $6.72 *$ & 1.76 & 2.28 & $0.721^{* *}$ \\
\hline $\mathrm{Hb}$ & 15.3 & $-0.0182^{* *}$ & 0.0976 & -0.0641 & 0.134 & -0.0837 & -0.0542 & -0.104 & -0.0949 & $-0.329 * *$ & 0.0115 & $0.0218^{* *}$ \\
\hline
\end{tabular}

**Significant $(p<0.01), *$ Significant $(p<0.05)$. 
Table 4-4. Coefficients of general linear models in several physical health status parameters of workers in Y company

\begin{tabular}{|c|c|c|c|c|c|c|c|c|c|c|c|c|}
\hline \multirow[b]{2}{*}{ Indicators } & \multirow[b]{2}{*}{ Intercept } & \multirow[b]{2}{*}{ Age } & \multicolumn{10}{|c|}{ Coefficients } \\
\hline & & & $\begin{array}{c}\text { Slecp } \\
\text { time }\end{array}$ & $\begin{array}{l}\text { Work } \\
\text { time }\end{array}$ & Holiday & $\begin{array}{c}\text { Break- } \\
\text { fast }\end{array}$ & Snack & $\begin{array}{c}\text { Soft } \\
\text { drinks }\end{array}$ & Alcohol & Smoking & Exercise & $\begin{array}{l}\text { Obesity } \\
\text { Index }\end{array}$ \\
\hline SBP & 96.2 & $0.303^{*}$ & 1.94 & 0.333 & 1.05 & 2.94 & -2.64 & 1.54 & -2.43 & 0.162 & 2.09 & $0.342 * *$ \\
\hline DBP & 54.7 & $0.477^{*}$ & 1.13 & 0.370 & -0.725 & 1.86 & -4.79 & -0.391 & $-2.71 *$ & 1.85 & 0.533 & $0.269 * *$ \\
\hline GOT & 20.7 & 0.0253 & 0.332 & 0.0163 & -2.71 & 0.445 & 0.770 & 0.0867 & -1.21 & 0.258 & -0.270 & $0.236 * *$ \\
\hline GPT & 18.8 & 0.0182 & 0.256 & 0.193 & -7.09 & 0.138 & 2.06 & 0.734 & 1.64 & 1.56 & 0.987 & $0.848 * *$ \\
\hline$\gamma_{\mathrm{GTP}}$ & 19.3 & $0.667^{*}$ & -0.180 & -0.744 & -1.84 & 0.123 & 3.85 & 0.949 & $-10.7^{* *}$ & 1.47 & 4.07 & $0.503^{* *}$ \\
\hline T-CHO & 59.8 & $1.85^{* *}$ & $5.92^{*}$ & 1.41 & --2.85 & -6.85 & 14.4 & -2.11 & 2.21 & 0.122 & -3.78 & $0.555^{* *}$ \\
\hline TG & 41.5 & $1.67 *$ & 7.03 & 3.38 & $\cdots 8.84$ & 0.845 & 7.18 & -13.0 & 3.06 & $-16.2^{*}$ & 8.95 & $2.27^{* *}$ \\
\hline RBC & 497 & -0.515 & 2.83 & 0.296 & 13.9 & -5.08 & -12.9 & -1.44 & 5.03 & 2.38 & 3.87 & $0.555^{* *}$ \\
\hline $\mathrm{Hb}$ & 15.3 & -0.0140 & 0.0739 & 0.0296 & 0.146 & -0.0735 & -0.161 & -0.150 & -0.0484 & --0.107 & 0.102 & $0.0159^{* *}$ \\
\hline
\end{tabular}

**Significant $(\mathrm{p}<0.01), *$ Significant $(\mathrm{p}<0.05)$.

Table 5. Coefficients of general linear models in mental health status (SDS) of workers

\begin{tabular}{|c|c|c|c|c|c|c|c|c|c|c|c|c|c|}
\hline \multirow[b]{2}{*}{ Indicators } & \multirow[b]{2}{*}{ Company } & \multirow[b]{2}{*}{ Intercept } & \multirow[b]{2}{*}{ Age } & \multirow[b]{2}{*}{$\begin{array}{c}\text { Sleep } \\
\text { time }\end{array}$} & \multirow[b]{2}{*}{$\begin{array}{l}\text { Work } \\
\text { time }\end{array}$} & \multirow[b]{2}{*}{ Holiday } & \multirow[b]{2}{*}{$\begin{array}{c}\text { Break- } \\
\text { fast }\end{array}$} & \multicolumn{2}{|c|}{ Coefficients } & \multirow[b]{2}{*}{ Alcohol } & \multirow[b]{2}{*}{ Smoking } & \multirow[b]{2}{*}{ Exercise } & \multirow[b]{2}{*}{$\begin{array}{l}\text { Obesity } \\
\text { Index }\end{array}$} \\
\hline & & & & & & & & Snack & $\begin{array}{c}\text { Soft } \\
\text { drinks }\end{array}$ & & & & \\
\hline SDS & K & 51.6 & $-0.152 * *$ & $-0.728^{*}$ & 0.0172 & -0.489 & 1.36 & -1.39 & $-1.08^{*}$ & 0.0918 & -0.701 & $1.42 * *$ & 0.0156 \\
\hline SDS & $\mathrm{H}$ & 50.1 & $-0.0734 *$ & -0.379 & -0.191 & $2.52^{*}$ & $-2.04 *$ & $-2,86^{*}$ & -0.736 & 0.952 & -0.110 & 1.25 & -0.0377 \\
\hline SDS & $Y$ & 44.1 & -0.0246 & $-1.35^{*}$ & 0.459 & 3.87 & -0.496 & -1.25 & -0.199 & 0.264 & $-2.60^{* * *}$ & 1.35 & -0.0247 \\
\hline SDS & All workers & 48.8 & $-0.133^{* *}$ & $-0.736^{* *}$ & -0.0464 & 1.06 & -0.0721 & 1.55 & -0.946 & 0.288 & $-0.975^{*}$ & $1.40^{* *}$ & -0.00540 \\
\hline
\end{tabular}

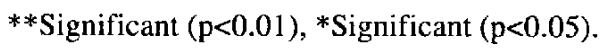

manufacturing companies enjoy more average annual holidays than in other kinds of companies in general, and blue-collar workers tend to enjoy holidays with greater physical and mental satisfaction than white-collar workers.

In this cross-sectional study, the obesity index was significantly related to all indices of physical health status in all three companies. In Japan all employers are under obligation to make workers undergo medical examinations. Any company which employs 50 or more workers is also under obligation to designate an occupational physician. Especially since the amendment to the Industrial Safety and Health Law in 1996, health care, such as counseling by an occupational physician or public health nurse, has been enforced, but the results of this study show that obesity influenced physical health in all three companies, suggesting that obesity is one of the most difficult lifestyle factors to improve.

Kaneko reported that consumption of alcohol affected liver function, and smoking affected blood pressure in studies on a Japanese car-manufacturing company and a Japanese car-sales company ${ }^{21)}$. Metzner reported that drinking and smoking are related to eight kinds of health measures, whereas eating breakfast and sleeping time are not $^{22)}$. Whitehead reported that $\mathrm{Hb}$ is significantly increased in smokers, and $\mathrm{RBC}$ is reduced by alcohol consumption ${ }^{23)}$.

In this study, sleeping time, eating breakfast, consumption of alcohol and smoking were related to blood pressure in all groups of workers. Consumption of alcohol was related to $\gamma$-GTP. Habitual physical exercise was related to RBC. Sleeping time and smoking were related to $\mathrm{Hb}$. The effects of sleeping time, eating breakfast, consumption of alcohol and smoking varied among the three companies. These results may be attributable to differences in job type (blue-collar or white-collar), educational level (graduated high school or university) and work shift (shift work or daytime work). In addition, the average age at $Y$ company was lower than that at the other companies.

Only obesity was significantly related to all indices of the physical health status of workers in all three companies. The lifestyle of workers with any serious physical disorders might have already been improved by health education. This may be one reason why no relationship between lifestyle and physical health status 
was found in this cross-sectional study. But obesity was significantly related to all indices of physical health status in all three companies. Obesity is supposed to be the most important lifestyle factor which affects health status. Therefore devising measures to counteract obesity is thought to be the most urgent matter in the management of workers' health.

Irie reported that alcohol drinking and smoking were associated with worsening of mental health status, whereas habitual physical exercise affected an improvement in mental health status in a working population ${ }^{24}$. It was also reported that mental health status reflects lifestyle ${ }^{25}{ }^{31}$. . Morimoto reported that habitual physical exercise, consumption of alcohol, lack of attention to dietary habits, and excess soft drink consumption relate to mental health status factors such as SDS, but sleeping time or smoking in male habitants did not related to it significantly ${ }^{321}$.

In this study, age, sleeping time, smoking and habitual physical exercise significantly affected to the index of mental health status only in the analysis of all workers. But in the analysis of each company, age and sleeping time were significantly related to the index of mental health status in $\mathrm{K}$ and $\mathrm{Y}$ companies. Smoking was significant to the index of mental health status in $Y$ company and habitual physical exercise in $\mathrm{K}$ company. Consumption of alcohol was not significantly related to the index of mental health status in any company.

It was thought that differences in the influence of sleeping time among the three companies were due to the difference in shift work: 2 shift work (K company), 3 shift work (H company) and daytime work (Y company). In addition, the distribution of sleeping time in $Y$ company was different in $\mathbf{K}$ and $\mathrm{H}$ companies. Two shift work requires constant overtime work, and most of the workers in $\mathrm{Y}$ company were engaged in research and development which are known to require overtime work. The difference in the distribution of working time among the three companies sustains this argument. In these populations, prolonging sleeping time may reduce the SDS score.

SDS scores of non-smokers were significantly lower than those of smokers only in Y company and in all workers, although the reasons were not clear.

It seems that habitual exercise reduced the SDS score in all workers and in K company, and similar coefficients were observed in $\mathrm{H}$ and $\mathrm{Y}$ companies but were not significant.

This result partly agrees with previous reports ${ }^{2431)}$. No common lifestyle which is significantly relevant to mental health status was found in any of the three companies. It can be said that lifestyle may affect mental health status less than physical health status.

Nowadays it is reported that worker's stress has been increasing due to the complicated nature of work and to other factors such as changes in work circumstances, changes in the type of employment, or restructuring of companies.

In the administration of workers' health, understanding the actual conditions of work in detail is therefore required at each company. Further investigations which include estimating the index of a healthy lifestyle must be conducted with regard to workers' health administration in Japan.

\section{References}

1) Belloc NB, Breslow L, Hochistin JR. Measurement of physical health in a general population survey. Am J Epidemiol 1971; 93: 328-336.

2) Belloc NB, Breslow L. Relationship of physical health status and health practices. Prev Med 1972; 1: 409421.

3) Belloc NB, Breslow L. Relationship of health practices and mortality. Prev Med 1973; 2: 67-81.

4) Berkman LF, Breslow L Health and ways of living-the Alameda County Study. New York: Oxford Univ. Press, 1983.

5) Morimoto K. Life Style and Health (Japanese). Tokyo: Igaku Shoin, 1991; 101-116.

6) Tarumi K, Hagihara A, Morimoto K. An inquiry into the relationship between job strain and blood pressure in male white-collar workers. Jpn J Ind Health 1993; 35: 269-276.

7) Kondo H, Morimoto K. Effects of lifestyle on hematologic parameters. Jpn J Ind Health 1993; 35: 98-104.

8) Kusaka Y, Kondo H, Morimoto K. Healthy lifestyles are associated with higher natural killer cell activity. Prev Med 1992; 21: 602-615.

9) Inoue $\mathrm{C}$, Takeshita $\mathrm{T}$, Kondo $\mathrm{H}$, Morimoto $\mathrm{K}$. Healthy lifestyles are associated with higher lymphokineactivated killer cell activity. Prev Med 1996; 25: 717 724.

10) Zung WWK. A self-rating depression scale. Arch Gen Psychiatry 1965; 12: 63-70.

11) Zung WWK, Darham NC. From Art to Science- The Diagnosis and Treatment of Depression. Arch Gen Psychiatry 1973; 29: 328.

12) Fukuda K. Self-rating depression scale Japanese Edition. Kyoto: Sankyobo, 1973.

13) Kato I, Tominaga S, Suzuki T. Lifestyle differentials by occupational group. Jpn J Public Health 1992; 39: 830-838.

14) Pratt $L$. The relationship of socioeconomic status to health. Am J Public Health 1971; 61: 281-291.

15) Fox AJ, Goldblatt PO, Jones DR. Social class mortality differentials: artefact, selection or life circumstances? J Epidemiol Community Health 1985; 39: 1-8.

16) Marmot MG, McDowall ME. Mortality decline and widening social inequalities. Lancet 1986; 2: 274-276.

17) Yamaguchi $K$. Life and fatigue of the shiftworkers with two days off in the weekend. Jpn J Ind Health 1992; 34: 652-655.

18) Kondo H, Kusaka Y, Morimoto K. Effects of lifestyle 
on hematologic parameters; Analysis of hematologic data in association with smoking and age. Jpn J Ind Health 1993; 35: 98-104.

19) Wakai K, Kawamura T, Ohno Y, et al. Life style and renal damage - association of smoking, drinking, and physical activity with subsequent proteinuria. Jpn J Public Health 1995; 42: 243-248.

20) Takeda F, Kawata C, Sonoda K, Kato T, Uchiyama K. A study of the relationship between job type and/or position to lifestyle and health of male white-collar workers. Jpn J Public Health 1992; 39: 326-340.

21) Kaneko M, Oda N, Wada N, Okazaki I. The study of the relation between the working conditions and the prevalences of obesity, liver disorder and hyperlipidemia: Evaluation of physiological examination data during the terms of car manufacturing work and car saleswork. J Occup Health 1995; 37: 3341 .

22) Metzner HL, Carman WJ, House J. Health practices, risk factors, and chronic disease in Tecumseh. Prev Med 1983; 12: 491-507.

23) Whitehead TP, Robinson D, Allaway SL, Hale AC. The effects of cigarette smoking and alcohol consumption on blood haemoglobin, erythrocytes: a dose related study on male subjects. Clin Labo Haematol 1995; 17: 131-138.

24) Irie $M$, Miyata $M$, Nagata $S$, Mishima $N$, Ikeda $M$, Hirayama $S$. The relationship between workers' attitudes towards health, lifestyle and mental health. Jpn J Ind Health 1997; 39: 107-115.

25) Lam TH. Mental health and work stress - comparison of response patterns in executives and clerical workers in Hong Kong. J Occup Med 1987; 29: 892-897.

26) Ezoe $S$, Morimoto K. Behavioral lifestyle and mental health status of Japanese factory workers. Prev Med 1994; 23: 98-105.

27) Izutkin DA, Kvasov SE, Kopteva LN. Self-evaluation by workers of health status and its relation to the life style. Sovetskoe Zdravookhranenia 1991; 2: 41-44.

28) Iwata N, Okuyama Y, Kawakami Y, Saito K. The twelve-item General health Questionnaire among Japanese workers. Environ Science Hokkaido Univ. 1988; 11: 1-10.

29) KasI SV. Mental health and work environment; an examination of the evidence. J Occup Med 1973; 15: 509-518.

30) Eisenberg L. A Research framework for evaluating the promotion of mental health and prevention of mental illness. Public Health Rep 1981; 96: 3-19.

31) Kawakami N, Haratani T, Kaneko T, Koizumi A. Relationship between health practices and depressive mood among industrial workers. Jpn J Ind Health 1987; 29: 55-63.

32) Morimoto K. Life Style and Health (Japanese). Tokyo: Igaku Shoin, 1991: 172-178. 